\title{
Rastafarian Perceptions of the Christian Burial of Emperor Haylä Śəllase I (2000)
}

\author{
Verena Böll
}

\section{1 \\ Introduction ${ }^{1}$}

The Ethiopian Orthodox ceremony of the Christian burial of Emperor Haylä Śllase I (1930-1974) took place in Addis Abäba, Ethiopia on 5 November 2000. The event has had a great local and global impact. Rastafarians worship Emperor Haylä Śllase as God and Messiah. They were skeptical about the event and only a few attended. In my paper I will describe the sequence of the burial and present some comments from the Rastafarians on this ceremony.

\section{The Death of Emperor Haylä Śəllase}

Emperor Haylä Śəllase, the last emperor of Ethiopia, ruled as emperor from 1930 until 1974. Born on 23 July 1892 as Prince Täfäri Mäkwännən he was appointed regent and throne successor in $1916 .^{2}$ On 2 November 1930 he was enthroned and crowned in the Gännätä Şəge Giyorgis (Qəddus Giyorgis) in Addis Abäba as emperor. His reign ended in 1974 after 44 years. ${ }^{3}$ On Septem-

1 My scheduled paper Funerals of Ethiopian Orthodox Christians in Germany was postponed because the first part of our documentary on the burial of Emperor Haylä Śllase (see fn. 7) was shown in the film panel "Ethiopian Studies through Image, Sound and Beyond: Perspectives from Ethnographic films" by Itsushi Kawase during the 2oth International Conference of Ethiopian Studies and I could present some details in the panel "Ethiopian Christianity: Global Interconnections and Local Identities” organized by Martin Tamcke and Stanislau Paulau.

2 He was proclaimed with the rank and title Ras in 1916 and started immediately his efforts of Ethiopian Modernity, see: Stanislau Paulau, "Isaac of Niniveh, Ras Täfäri and the Making of Ethiopian Modernity," in Acts of the Symposium Syriacum 2016, ed. Emidio Vergani et al. (forthcoming).

3 On his person and reign, see: Christopher Clapham, "Haylä Śəllase," in EAe 2 (2005): 106o1066. 
ber 11, 1974, Haylä Śəllase was deposed and locked up in a wing of the palace. There he died as a prisoner on 26 August $1975 .{ }^{4}$ His body was secretly buried in the palace grounds.

The collapse of the socialist military government of Mängəśtu Haylä Maryam in 1991 allowed family members to search for his remains. They were discovered in 1992 and for the time being kept in the church of the palace, the Bäatä Maryam church. ${ }^{5}$ After the end of the Transitional government and the start of the Federal Republic of Ethiopia in 1995 different efforts started to organize a Christian burial and a state funeral. The time had come on November 2000 and lasted three days.

The November 2000 was chosen mainly due to the coronation day of the emperor, but also because of the 14th International Conference of Ethiopian Studies, during which an international audience was already present in Addis Abäba. ${ }^{6}$ All foreign participants of the Conference have been invited to attend the solemnity on Sunday, 5 November 200o, and numerous visitors witnessed the ceremony, this applies also for me and two other researchers, Günther Schlee and Georg Haneke (d. 2017). They filmed the ceremony at different places and the footage was stored in the Max Planck Institute for Social Anthropology, Halle (Saale), Germany. A three-year research project (Haylä Śəllase Film Project, October 2016-July 2019) enabled me, assisted by Ambaye Ogato and Robert Dobslaw to produce a two-part documentary on the ceremony and the perspectives of the Rastafarians about the death and burial of the emperor. ${ }^{7}$

\section{The Christian Burial of Emperor Hुaylä Śəllase}

Haylä Śəllase was officially buried only 25 years after his death. For Ethiopian Orthodox Christians this violates the existing rites of mourning and burial

4 The discussion about the date of his death and the circumstances, if he was murdered are currently being revived by the opening of the archives and the emergence of new documents.

5 The Bäatä Maryam church is the mausoleum of Emperor Mənilək II, who died in 1913 but was buried only in 1916, see: Estelle Sohier, "Le corps des rois des rois dans la ville: Ménélik II et Haylé Sellasé à Addis Abeba," Afriques. Débats, méthodes et terrains d'histoire 3 (2011), https://doi.org/10.400o/afriques.1015.

6 The 14th International Conference of Ethiopian Studies took place at the University of Addis Abäba from 6 to 11 November 2000.

7 Verena Böll, Georg Haneke, Günther Schlee, Ambaye Ogato and Robert Dobslaw, Emperor Haile Selassie I. His Burial and the Rastafarians in Shashamane, Ethiopia. A two-part Documentary, Max Planck Institute for Social Anthropology, Halle (Saale), Germany, Part 1 2018, 45 min., Part 2 2019, 49 min., https://www.eth.mpg.de/cms/en/media/haile-selassie-film-project. 
which are supposed to take place in a precisely prescribed sequence immediately after the death. ${ }^{8}$ The funeral traditionally takes place the same day. ${ }^{9}$ The funeral rite and liturgy include the caring for the dying, the wake, the prayer of absolution and the ablution of the death. Due to the circumstances of the death of Haylä Śllase and that all his closest relatives were imprisoned these rites could not be performed. And when his corpse was discovered in 1992 it was just bone. But regarding the other parts of the mourning rites there was the possibility of carrying them out despite the time lag of a quarter century.

In the Ethiopian Orthodox culture, a funeral is a very important social moment. Relatives, friends, neighbors and other people participate. The number of participants provide information about the social position and rank of the deceased. The organizers of the burial of Haylä Śəllase got the permission from the government to perform the ceremony at different places and churches to guarantee a place for all mourners and to be able to fulfill the mandatory procession. ${ }^{10}$ The organizers, coordinated by the Emperor Haylä Śəllase I Memorial Foundation, the War Veterans Association, the Crown Council in exile and family members were sure that many people would attend.

The organizing committee defined three churches for the liturgical commemorations. The liturgy of the dead (requiem mass) was celebrated on 2 November 2000 in the Gännätä Șəge Giyorgis where he was crowned 70 years

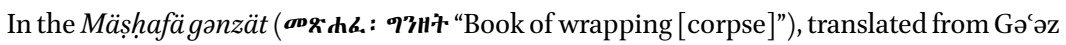
into Amharic titled Yäfothat mäshaf ("Book of absolution"), the prescribed prayers for burial liturgy are to be found. The best overview and translation of the Ethiopian liturgical books on mourning and burial offers Friedrich Erich Dobberahn, "Der äthiopische Begräbnisritus," in Liturgie im Angesicht des Todes. Judentum und Ostkirchen. Vol. 1, ed. Hansjakob Becker and Hermann Ühlein (St. Ottilien: Eos-Verlag, 1997), 137-316, 657683 (text); Friedrich Erich Dobberahn, "Der äthiopische Begräbnisritus," in ibid., vol. 2, 859-1036 (translation); Friedrich Erich Dobberahn, "Weitere Formulare zum äthiopischen Begräbnisritus," in ibid., vol. 3, 1397-1432; Friedrich Erich Dobberahn, "Das Gedenken an die Verstorbenen im äthiopischen Begräbnisritus," in ibid., 1469-1486, 1506-1508.

9 The globalization and the fact that at least one member of a household is living in another city or land changes the tradition. Funerals are still carried out immediately (there are only a few cold stores in Ethiopia) but the liturgical ceremonies are increasingly postponed to enable all relatives to travel home and to participate.

10 On the procession, see: Verena Böll, "Die Anwesenheit von Klageweibern bei der Bestattung von Kaiser Haylä Śəllase im Jahr 200o," in Ägypten und der Christliche Orient. Peter Nagel zum 80. Geburtstag, ed. Heike Behlmer, Ute Pietruschka and Frank Feder (Wiesbaden: Harrassowitz, 2018), 39-46; Anaïs Wion, "Onction des malades, funérailles et commémorations: pour une histoire des textes et des pratiques liturgiques en Éthiopie chrétienne," Afriques. Débats, méthodes et terrains d'histoire 3 (2011), https://doi.org/10.40oo/ afriques.921. 
ago. ${ }^{11}$ On Sunday, 5 November, the solemn funeral started with a liturgy at the Bäatä Maryam church at the Palace compound, where his bones have been kept since 1992, followed by prayers in the Gännätä Ṣəge Giyorgis and the main liturgy at the Holy Trinity Cathedral (Qəddəst Śəllase Cathedral). Haylä Śəllase had the Cathedral built in 1933 (the construction was interrupted by the Italian invasion and was completed in 1943) to be his court church and his final resting place. His consort Empress Mänän (d. 1962) has her grave there in the chapel and the other family members are laid out there in granite coffins in the crypt.

The burial ceremony of Emperor Haylä Śllase was planned by the organizers as a state funeral, but only a few days before the date it was cancelled by the government and the ceremonies were only allowed to be held on a smaller scale. ${ }^{12}$ This was also noticeable on the Meskel (Mäsqäl) Square where many chairs remain empty. After the prayers in the Bäatä Maryam church early in the morning the red granite coffin, draped in the Ethiopian flag, with the mortal remains of Haylä Ślllase was brought in a car procession to this place. There, the coffin was set out in the middle of the square, guarded by members of the Imperial guards in their specific uniforms with baboon headdresses and lion's mane cape worn over a striped silk tunic. After liturgical chants, addresses and the funeral oration by the grandson Bäədä Maryam Mäkwännən, ${ }^{13}$ the funeral procession continued to the church of Gännätä Ṣəge Giyorgis. The granite coffin was put on a decorated pickup, the veterans took up their position on the truck by standing the whole procession besides the coffin. After a short stop in the Gännätä Ṣəge Giyorgis the funeral procession, consisting of cars and walkers, continue to the Cathedral of the Holy Trinity. It is here that most of the participants of the 14th Interntional Conference of Ethiopian Studies attended as guests. They could witness the ceremonial arrival of Patriarch Pawlos, who presided over the ceremony at the church forecourt. After a while the pickup with the coffin arrived and the choirs started to sing. The coffin was laid out and the liturgical ceremony started. The dance and the rhythmical singing by the däbtära using the sistrum and the ceremonial stock (mäqqwamiya) around

11 Many guests from abroad attended the coronation in 1930 and the international press reported abundantly. It was the wish of the organizers that this should also be possible at the funeral ceremony.

12 Interview with Liqä kahənat Abbaye, Abbäbä Bäqqälä and Nəguśä Ambo of the Haile Selassie I Memorial Foundation on October 2018 in Addis Abäba. Together with my colleague Ambaye Ogato I conducted two interviews with the board of directors. The results of these and other interviews, which could not be included in the film, will be published in articles.

13 He was imprisoned until 1989 and lives now in Addis Abäba. We interviewed him in October 2018. 
the coffin was part of the ecclesiastical rite but also symbolized the dignified farewell of the last emperor of Ethiopia. Speeches by Abunä Gärima and Patriarch Pawlos recalled Hyaylä Śllase's support for the church and his contributions to Ethiopia, Africa and the entire world. Finally, the coffin was taken by the emperor's grandchildren and great-grandchildren on their shoulder and they walk slowly towards the church. Inside the church, Patriarch Pawlos gives his blessings. The flag, in which the coffin was draped, was folded and handed over to the last daughter still alive, to Princess Tänaññä Wärq (d. 2003). The coffin and that of Empress Mänän are now standing side by side in the cathedral's chapel.

\section{Rastafarian Perceptions}

Is His Imperial Majesty, Emperor Haylä Śəllase, King of Kings of Ethiopia, Lord of Lords, Conquering Lion of the Tribe of Judah, Elect of God, really dead? The Rastafarians doubt or deny this. Rastafarians, attributing their name on the first title (Ras) and birth name (Täfäri) of Haylä Śəllase, live in different places in Ethiopia, but their main living area is Šašämäne. ${ }^{14}$ In Šašämäne we conducted long-durée interviews with 15 Rastafarians about their belief and their comments on his announced death (1975) and his burial (2000). ${ }^{15}$ The Rastafarians belong in Šašämäne mainly to the houses (mansions) of Nyabinghi, the Twelve Tribes or the Ethiopian World Federation. ${ }^{16}$

14 Emperor Hुaylä Śəllase granted land in Šašämäne to the "black people of the world" as a thank-you present for their support during the Italian invasion and occupation (19351941), see: Kevin A. Yelvington, "Jamaica and the Caribbean," in EAe 3 (2007): 266-267. Since 1948 black people repatriate to Ethiopia to live in the only sovereign nation. The first Rastafarian from the Caribbean, especially Jamaica, came in 1968 to Ethiopia and settled in Šašämäne, see: Giulia Bonacci, "An Interview in Zion. The Life-History of a Jamaican Rastafarian in Shashemene, Ethiopia," Callaloo 34, no. 3 (2011): 744. Since then the Rastafarian community in Šašämäne became international, including Rastafarians with European origin.

15 The second part of our documentary points out the perspectives of the Rastafarians about the death and burial through interviews with Rastafarians in Šašämäne, Ethiopia. On the website of the Max Planck Institute for Social Anthropology, Halle (Saale), Germany, 2019 a film booklet and a postcard booklet provide further information about the research and the interviewees: https://www.eth.mpg.de/cms/en/media/haile-selassie-film-project.

16 See Giulia Bonacci, "Rastafari/Rastafarianism," in EAe 4 (2010): 339-340 and for a detailed overview Giulia Bonacci, Exodus! Heirs and Pioneers, Rastafari Return to Ethiopia, trans. Antoinette Tidjani Alou (Kingston: The University of the West Indies Press, 2015). The 


\subsection{Rastafarian Belief System and the Death of Emperor Haylä Śallase}

The Rastafarian movement is characterized by individualism and freedom, there is no central structure or head and some Rastafarians do not belong to a certain house. Part of them are members of Ethiopian churches, in Ethiopia especially of the Ethiopian Orthodox Täwahədo Church. Two points are common among all Rastafarians, the veneration of Emperor Haylä Śllase and the appraisal of Ethiopia as the promised land.

The Bible is the most read book by the Rastafarians. During the conversations they quote Bible passages, mostly from the Leviticus and other books of the Old Testament. Other scriptures of the Ethiopian Orthodox Täwahədo Church are well known. Besides the Christian scriptures the speeches of Haylä Ślllase are intensively studied and cited as well.

The relation between the Rastafarians and representants of the Ethiopian Orthodox Church is inconsistent. The Ethiopian Orthodox Church accepts the movement on certain points and the Rastafarians are welcomed by the church. It is possible to be both, baptized member of the church and Rastafarian. Rastafarians in Europe have their children baptized in the Ethiopian Orthodox Church, one reason being the search for spiritual and physical closeness to Ethiopia. ${ }^{17}$ During his lifetime Haylä Śllase was the (secular) head of the church and becoming member of the Ethiopian Orthodox Church means to be part of his religious and spiritual realm. For the Rastafarians the millennium started with the coronation of Haylä Śəllase in 1930 and in the end, there will be a D-day, a final judgement.

Ras Kawintseb explained that there has been always a biblical relation between Israel, Ethiopia, Jesus Christ and Hyaylä Śllase. The inscription INRI above the cross of Jesus means "I Nəguś rule Israel." This is a popular Interpretation among the Rastafarians in Šašhämäne. ${ }^{18}$

Sister Ijahnya states that she gives thanks and praises in the name of His Imperial Majesty Haylä Śəllase and praises to Empress Mänän. The name Hुaylä Śllase means power of the Trinity. And the Trinity for them is not three male persons, but the father, the mother and the child which is the basis of the African family. The Trinity is eternal and can never die.

For the Rastafarian Sandrine, Alex and Jaden, Haylä Śllase of Ethiopia is God and Messiah. But they refer to biblical figures as well and through Haylä Ślllase Jesus Christ is transformed to a Black Christ. Alex argues that Haylä

Ethiopian perspective is included in Erin C. MacLeod, Visions of Zion: Ethiopians and Rastafari in the Search for the Promised Land (New York: New York University Press, 2014).

17 Merawi Tebege, "Rastafari und die Äthiopisch-Orthodoxe Kirche," Salama 35 (2005): 35.

18 Interview 7 May 2019. Naguś is the Amharic word for King. 
Śllase conquered death as Christ did. Jesus Christ is risen from the dead and Christians believe in his second coming and for him Haylä Śllase is the resurrected Christ. They explain that Haylä Śllase did Christian deeds and followed the Bible. They do not believe the story of his death and the presented evidences. Haylä Śllase is alive, he is a messiah, a king, a living black Christ. Alex says, "I don't believe in white Christ." They argue that history and religion are always two different things. Religion has to do with belief and not with evidence. People believe that Christ has arisen and Rastafarian believe that Haylä Śllase is alive, there is no difference. History deals with facts, but even history needs proofs and research. And until today no prove about the death and the dead body of Haylä Śəllase was submitted. ${ }^{19}$

Ras Fwè Jah Jah says that he does not want to talk about the death of Haylä Śllase as he does not believe in it; instead, he wants to talk about love. He believes that love is what Hुaylä Śəllase represents and Huylä Śllase is God, a creator and created everything. He argued that a funeral is a "men-thing," Mängəśtu Haylä Maryam is man, all organizers are men, but Qädämawi (the first) Haylä Śllase is spiritual, he is God. We must talk only about these positive vibrations. ${ }^{20}$

For Che Peter Lee, Haylä Śllase is a king of kings, but he never worships Haylä Ślllase as God. He refers to the Bible, "the Bible told us that Israel was never short of a prophet and that is why we love Haylä Śllase." He is sceptical about the death of the emperor and argued that he believes Haylä Śəllase as a spiritual person, he is from God and so it is hard to say that he is dead, or someone killed him. He cannot say Haylä Śəllase is dead because he does not believe in that. ${ }^{21}$

Ras Iron Gad and Elder Zion Gad compare the crises after the death of Christ 2000 years ago with the one after the alleged death of Haylä Śllase. And as the Ethiopian Church is one of the oldest churches in the world, the Rastafarians had to establish their community on this land given in Ethiopia by the emperor. Ethiopia is Zion for the Rastafarian “The black man's Zion ruled by their God and king, Haylä Śəllase."22

19 Interview with Alex and Jaden in August 2018 and with both and Sandrine in October 2018. Ras Ghion indirectly criticized this statement by saying: "He believes in colour," interview 10 May 2019. millennium (E.C.).

21 Interview in his Bolt house in May 2019.

22 Interview in a soup bar, 10 May 2019. In the soup bar they sell food, consisting of ingredients from own cultivation. 
Sister Linda and Mama Joan discuss the deification of Emperor Haylä Śəllase, and Sister Linda explains that Haylä Śllase is alive, he is a Messiah, but he is not divine. ${ }^{23}$ Ras Kawintseb and his friend Paul McIntosh handed over material that witnesses that Haylä Sollase is alive. Among others a video with an interview with an Indian who saw Haylä Ślllase in London in the 1980s. Ras Kawintseb stresses that even if Haylä Śllase is not present in person, his ideas are always present among the Rastafarians. He is immortal, immortal for the whole world. ${ }^{24}$

Sister Ijahnya, Ras Iron Gad and Elder Zion Gad told that Haylä Śllase lives in Lalibäla as a bahtawi. He was seen there several times. The bahtawi, Ethiopian Orthodox hermits, have a high value among the Rastafarians. ${ }^{25}$ Ras Ghion emphasised that Emperor Haylä Śəllase is living, he is 126 years. The holy old people, the bahtawi in the holy mountains told him that the emperor is not dead. For him the bahtawis are holy men, strongly disciplined, living a pure life, dedicated to God. They are the real arbäññočč (patriots). ${ }^{26}$

What become clear through the interviews is that the denial of the death and the burial are closely linked together. When Haylä Śəllase died, an attempt was made to keep that secret and his corpse was not shown, no relatives saw him dead. The prescribed rituals of the church could not be performed. Some of the Rastafarians are members of the Ethiopian Orthodox Täwahədo Church and they accept the funeral rites of the church. But because these rites could not be fulfilled, he could not be dead. Both arguments were given by the interviewees to emphasize that he is not dead. He only disappeared in August 1975 and is still alive.

\subsection{The Bones}

Another argument was mentioned again and again by the Rastafarians: The question regarding the bones. When in 1992 the remains of Haylä Śllase were found at the palace compound, the international newspaper and TV channels documented the digging for the bones. In the film The Emperor's Birthday by John Dollar (1992) one interviewee, Noel Dyer explains, that the Rastafarians from all over the world gather in 1992 to celebrate the centennial birthday (23 July) of Haylä Śəllase in Addis Abäba and that the appearance of the bones

\footnotetext{
23 Interview May 2019 in the Restaurant Bolt house of Che Peter Lee, the son of Mama Joan.

24 Meeting with Ras Kawintseb and Paul McIntosh in the garden of Ras Kawintseb, 8 May 2019 .

25 Interview in a soup bar, 10 May 2019.

26 Interview in his hut, August 2018.
} 
at this very moment was very confusing. ${ }^{27} \mathrm{He}$ emphasizes that His Majesty is alive and that they will celebrate a living king and not a dead bone. The pilgrimage of the Rastafarians to Addis and their presence at the most important places for Haylä Śllase, like the Palace, the University, the headquarter of the African Union and their performances at the National Theatre was perceived positively by the residents. The memories of Haylä Śllase, who had been suppressed during the dictatorship, came back. In some reports it was said they came for a supposed burial instead for the centenary, but all interviewees denied this. ${ }^{28}$

Numerous arguments have been raised against the alleged bones of Haylä Śəllase. Ras Kawintseb mentions the missing autopsy and medical examination of the bones. It exists no certificate of death. A DNA test and analysis were not performed. Nowadays old bones can be dated exactly, so why they did not make a DNA test? He also comments the size of the bones, especially the thighbone. Haylä Śəllase was short in stature, but the bones discovered were very large. The same is true for the sarcophagus, it did not fit, and that cannot be as the Ethiopian craftsmen are masters. ${ }^{29}$

\subsection{The Burial}

The burial rites of the Ethiopian Orthodox Church are a controversial issue. Ras Kabinda said that the Rastafarians have a different concept of death. ${ }^{30}$ The mourning, the lamentations, the regulations and limitations for a year after the death of a relative they do not practice. Dying happens and life goes on. The death is accepted, and funerals should not be a big deal. ${ }^{31}$

Ras Kawintseb said that the burial in 2000 was a propaganda and a fake. It was not a state burial, but a public one. Ras Ghion does not believe that

27 John Watt Dollar, The Emperor's Birthday (Ethiopia / USA, 1992), $5^{2}$ min., https://search .alexanderstreet.com/preview/work/bibliographic_entity\%7Cvideo_work\%7C1689423. Noel Dyer is well-known by the Rastafarians as the one who walked to Ethiopia. He is the father of Jonathan Dyer, whom we interviewed in May 2019. On the film, see the review of John Homiak. Homiak discusses the postmodern idea of "Travelling Cultures" by James Clifford and shows that the filmmaker uses the door of a hotel as symbol for the culture-astravel. John Homiak, "Rastafari Voices Reach Ethiopia," American Anthropologist 96, no. 4 (1994): 962.

28 About the Rastafarians during the Derg time, see: Bonacci, "An Interview," 753.

29 Interview October 2018. Ras Kawintseb lived in Šašhämäne for more than twenty years. He is a musician and artist.

30 Interview 10 May 2019.

31 The question, where to bury dead Rastafarians in Šašhämäne, is not solved, see: Carsta Schnabel, Heimkehr aus Babylon. Rastafari repatriieren nach Äthiopien (Köln: Köppe, 2017). 
Haylä Śllase is dead as no official of the Därg regime acknowledged the death of Haylä Śllase. For him the burial was a great crime, a drama played by the government to bury the Imperial system and institute a new federalism system. The government took eight years to prepare the drama. Rastafarians fights against Babylon, they cannot accept the burial. ${ }^{32}$

Sister Berenice phrased it like that: "It is just a big joke. If you don't have a body, you don't have a dead person to bury." Jonathan Dyer remembers when he was a little kid he heard that Haylä Śllase is dead and his father was so vexed and said: "Haylä Śllase did not die, how can they said that." Jonathan emphasises the significance of the new generation in Šašämäne. They do not care about the burial almost twenty years ago. Haylä Śllase is the reason their parents or grandparents came to Ethiopia. Haylä Śəllase is always present. ${ }^{33}$

\section{$5 \quad$ Conclusion}

The global interconnections between Ethiopia and the world can be shown by the person of Emperor Haylä Śəllase. The performance of this Orthodox burial in the year 2000, 25 years after his death got international attention. The ceremony caused a lot of controversy. The Rastafarians believe that Haylä Śllase is still alive and therefore it was not his burial.

\section{List of References}

Böll, Verena. "Die Anwesenheit von Klageweibern bei der Bestattung von Kaiser Haylä Śllase im Jahr 20oo." In Ägypten und der Christliche Orient. Peter Nagel zum 80. Geburtstag, edited by Heike Behlmer, Ute Pietruschka and Frank Feder, 39-46. Wiesbaden: Harrassowitz, 2018.

Böll, Verena, Georg Haneke, Günther Schlee, Ambaye Ogato and Robert Dobslaw. Emperor Haile Selassie I. His Burial and the Rastafarians in Shashamane, Ethiopia. A two-part Documentary. Max Planck Institute for Social Anthropology, Halle (Saale), Germany. Part 1 2018, 45 min., Part 2 2019, 49 min. https://www.eth.mpg.de/cms/en/ media/haile-selassie-film-project.

$3^{2}$ Interview October 2018. Babylon stands for the (western) world which follows the material goods and the evil thoughts.

33 Interview in May 2019, together with Sister Berenice. Jonathan told us the biography about his father, Noel Dyer. 
Bonacci, Giulia. "An Interview in Zion. The Life-History of a Jamaican Rastafarian in Shashemene, Ethiopia," Callaloo 34, no. 3 (2011): 744-758.

Bonacci, Giulia. "Rastafari/Rastafarianism." In EAe 4 (2010): 339-340.

Bonacci, Giulia. Exodus! Heirs and Pioneers, Rastafari Return to Ethiopia, translated by Antoinette Tidjani Alou. Kingston: The University of the West Indies Press, 2015.

Clapham, Christopher. "Haylä Śəllase.” In EAe 2 (2005): 106o-1066.

Dobberahn, Friedrich Erich. "Der äthiopische Begräbnisritus." In Liturgie im Angesicht des Todes. Judentum und Ostkirchen. Vol. 2, edited by Hansjakob Becker and Hermann Ühlein, 859-1036. St. Ottilien: Eos-Verlag, 1997.

Dobberahn, Friedrich Erich. "Das Gedenken an die Verstorbenen im äthiopischen Begräbnisritus." In Liturgie im Angesicht des Todes. Judentum und Ostkirchen. Vol. 3, ed. Hansjakob Becker and Hermann Ühlein, 1469-1486, 1506-15o8. St. Ottilien: EosVerlag, 1997 .

Dobberahn, Friedrich Erich. "Der äthiopische Begräbnisritus." In Liturgie im Angesicht des Todes.Judentum und Ostkirchen. Vol. 1, edited by Hansjakob Becker and Hermann Ühlein, 137-316, 657-683. St. Ottilien: EOs-Verlag, 1997.

Dobberahn, Friedrich Erich. "Weitere Formulare zum äthiopischen Begräbnisritus." In Liturgie im Angesicht des Todes.Judentum und Ostkirchen. Vol. 3, edited by Hansjakob Becker and Hermann Ühlein, 1397-1432. St. Ottilien: EOs-Verlag, 1997.

Dollar, John Watt. The Emperor's Birthday. Ethiopia / USA, 1992, $5^{2}$ min. https://search .alexanderstreet.com/preview/work/bibliographic_entity\%7Cvideo_work\%7C168 9423 .

Homiak, John. "Rastafari Voices Reach Ethiopia." American Anthropologist 96, no. 4 (1994): 958-963.

MacLeod, Erin C. Visions of Zion: Ethiopians and Rastafari in the Search for the Promised Land. New York: New York University Press, 2014.

Merawi Tebege. "Rastafari und die Äthiopisch-Orthodoxe Kirche." Salama 35 (2005): 23-35.

Paulau, Stanislau. "Isaac of Niniveh, Ras Täfäri and the Making of Ethiopian Modernity," in Acts of the Symposium Syriacum 2016, edited by Emidio Vergani, Manuel Nin, Sabino Chialà and Craig Morrison. Forthcoming.

Schnabel, Carsta. Heimkehr aus Babylon. Rastafari repatriieren nach Äthiopien. Köln: Köppe, 2017.

Sohier, Estelle. "Le corps des rois des rois dans la ville: Ménélik II et Haylé Sellasé à Addis Abeba." Afriques. Débats, méthodes et terrains d'histoire 3 (2011). https://doi .org/10.400o/afriques.1015.

Wion, Anaïs. "Onction des malades, funérailles et commémorations: pour une histoire des textes et des pratiques liturgiques en Éthiopie chrétienne." Afriques. Débats, méthodes et terrains d'histoire 3 (2011). https://doi.org/10.400o/afriques.921.

Yelvington, Kevin A. "Jamaica and the Caribbean." In EAe 3 (2007): 266-267. 